\title{
PREFERENSI HAMA KEPINDING TANAH (Scotinophara coartata F) PADA BEBERAPA VARIETAS TANAMAN PADI SAWAH
}

\section{PREFERENCES OF RICE BLACK BUG PEST (Scotinophara coartata F) ON SEVERAL VARIETIES PLANTS RICE}

\author{
Jandrio H. Moonik'1), Jusuf Manueke'), dan Dantje Taroreh2) \\ 1)Mahasiswa Entomologi Pascasarjana Unsrat Manado \\ 2)Dosen Fakultas Pertanian Unsrat Manado, 95115 \\ Email : rio.moonik@gmail.com
}

\begin{abstract}
Rice Black Bug (Scotinophara coartata F) is one of the most important pests that attack rice crops and has caused major losses. The purpose of this study is to determine the Rice Black Bug preferences in some varieties of rice crops. This research was conducted in Modomang Village, East Dumoga Subdistrict of Bolaang Mongondow Regency from November 2016 - February 2017. This research used Completely Randomized Design (CRD) with 5 treatments, namely several varieties of rice field cultivation (Ciherang, Cigeulis, Membramo, Pertiwi and Serayu).Based on the results of this study showed that the population of S. coartata pest with the largest average in Serayu varieties of 6 tails, followed by Membramo 3.75 tail, 3.5 Pertiwi, 3.5 Cigeulis and the lowest Ciherang with an average of 3.25 tail
\end{abstract}

Keywords: preferences, rice black bug pest, varieties plants rice

\section{ABSTRAK}

Hama Kepinding Tanah (Scotinophara coartata F) merupakan salah satu hama penting yang menyerang pertanaman padi sawah dan menyebabkan kerugian besar. Tujuan penelitian ini yaitu untuk mengetahui preferensi hama kepinding tanah pada beberapa varietas tanaman padi sawah. Penelitian ini dilaksanakan di Desa Modomang, Kecamatan Dumoga Timur Kabupaten Bolaang Mongondow dari bulan November 2016 - Pebruari 2017. Penelitian ini menggunakan metode Rancangan Acak Lengkap (RAL) dengan 5 perlakuan yaitu beberapa varietas tanaman padi sawah (Ciherang, Cigeulis, Membramo, Pertiwi dan Serayu). Hasil penelitian ini menunjukkan bahwa populasi hama S. coartata dengan rata-rata terbesar pada varietas serayu sebanyak 6 ekor, kemudian diikuti oleh membramo 3.75 ekor, pertiwi 3,5 ekor, cigeulis 3.5 ekor dan yang terendah ciherang dengan rata-rata 3.25 ekor.

Kata kunci : preferensi, hama kepinding tanah, varietas padi sawah 


\section{PENDAHULUAN}

Tanaman padi (Oryza sativa L.) merupakan tanaman pangan yang menghasilkan beras sebagai sumber makanan pokok sebagian besar penduduk Indonesia. Beras merupakan bahan makanan pokok utama dan sangat dominan di Indonesia yang memiliki kedudukan sangat penting dan telah menjadi komoditas strategis (Manurung dan Isumunadji, 2008). Kebutuhan beras selalu meningkat setiap tahunnya sejalan dengan peningkatan jumlah penduduk yang tidak diimbangi dengan produksi yang cukup. Kebutuhan beras di Indonesia mencapai 32 juta ton sedangkan produksi Nasional maksimal hanya mencapai sekitar 31,5 juta ton/ tahun (Darma, 2007).

Direktorat Jendral Tanaman Pangan Kementerian Pertanian (2016) merilis target produksi padi sasaran produksi tahun 2016 sebesar 76.226.00 Ton GKG. Luas panen 14.314.742 $\mathrm{Ha}$ dan Produktivitas 53,25 Ku/Ha. Produksi padi tahun 2015 sebanyak 75,36 juta ton gabah kering giling (GKG) atau mengalami kenaikan sebanyak 4,51 juta ton (6,37 persen) dibandingkan tahun 2014. Berdasarkan hal tersebut, kebutuhan beras sebagai bahan pangan pokok di Indonesia sangat tinggi.

Tinggi rendahnya produksi padi di Sulawesi Utara disebabkan beberapa hal, diantaranya adalah serangan hama dan penyakit. Serangan hama pada tanaman padi relatif tinggi setiap tahun. Serangan tersebut belum dapat dikendalikan secara optimal, sehingga mengakibatkan kerugian yang cukup besar baik kehilangan hasil, menurunnya mutu, terganggunya kontinuitas produksi, serta menurunnya pendapatan petani. Masalah hama dan penyakit yang semakin kompleks dirasakan oleh petani dari tahun ke tahun. Hal ini diduga akibat dampak perubahan iklim global yang berpengaruh terhadap pola musim/cuaca lokal yang sangat erat kaitannya dengan perkembangan hama. Disamping itu, permasalahan hama dan penyakit pada tanaman padi akan terus dihadapi karena luas lahan yang semakin berkurang, terbatasnya modal, pengetahuan dan keterampilan petani, permasalahan irigasi, pasar serta harga produksi (Gaib, 2011).
Organisme Pengganggu Tanaman (OPT) adalah setiap organisme yang dapat mengganggu pertumbuhan dan atau perkembangan tanaman sehingga tanaman menjadi rusak, pertumbuhannya terhambat, dan atau mati. UU No. 12 Tahun 1992 tentang sistem budidaya tanaman menyatakan bahwa Organisme Pengganggu Tanaman (OPT) adalah semua organisme yang dapat merusak, mengganggu kehidupan atau menyebabkan kematian tumbuhan (Sembel, 2011).

Kalshoven (1981) mengemukakan bahwa kepinding tanah (Scotinophara coartata) merupakan salah satu hama yang cukup penting dan menyebar pada pertanaman padi sawah di Sulawesi, Sumatera, Kalimantan dan Jawa. Hama ini menyerang pada fase vegetatif dan generatif dan telah menyebabkan kerugian yang besar. Tanaman yang terserang kepinding tanah dapat mengakibatkan penurunan produksi karena apabila menyerang pada fase anakan akan menyebabkan jumlah anakan berkurang dan pertanaman terhambat atau kerdil. Sedangkan kalau kepinding tanah menyerang pada saat setelah fase bunting, tanaman menghasilkan malai yang kerdil, tidak lengkap dan akan menghasilkan gabah hampa. Dalam kondisi populasi tinggi tanaman yang dihisap dapat mati (Nurjanah, 2010).

Menurut Rimbing, dkk. (2011) S. coartata merupakan hama yang menyerang dan menimbulkan kerusakan berat pada pertanaman padi sawah di Sulawesi Utara, khususnya di Kecamatan Dumoga. Hama ini telah menjadi hama utama di Kecamatan Dumoga karena populasi dan tingkat serangan yang cukup tinggi merusak pertanaman padi sawah dan meresahkan petani.

Di Kecamatan Dumoga populasi hama ini berkembang dengan pesat karena selain populasi musuh alami yang berkurang akibat penggunaan pestisida yang berlebihan, ketersediaan makanan atau inang.

Populasi hama ini berbeda pada setiap varietas tanaman padi sawah. Berdasarkan hal tersebut maka penelitian mengenai preferensi hama ini sangat perlu untuk diketahui.

Penelitian ini bertujuan untuk mengetahui preferensi hama kepinding tanah untuk berkem- 
bang biak pada beberapa varietas tanaman padi sawah.

\section{METODE PENELITIAN}

Penelitian dilaksanakan di Kecamatan Dumoga Kabupatan Bolaang Mongondow selama 4 bulan dari bulan November 2016 sampai dengan Pebruari 2017.

Bahan dan alat yang digunakan yaitu serangga objek $S$. coartata, tanaman padi sawah (varietas Ciherang, Cigeulis, Membramo, Pertiwi dan Serayu), kurungan serangga, pisau, cutter, hand counter, tali, gunting, kertas label, kertas, pulpen dan kaca pembesar (loop).

Penelitian ini diawali dengan penanaman beberapa varietas tanaman padi sawah kedalam media tanam (ember) yang telah disediakan dengan jumlah setiap varietas ditanam lima. Tanaman tersebut dimasukkan kedalam kurungan serangga yang terbuat dari jaring dengan ukuran $5 \times 1.5$ meter. Pelepasan serangga hama dilakukan setelah tanaman berumur 4 minggu.

Setelah pengambilan imago jantan dan betina hama kepinding tanah yang diambil langsung dari lokasi persawahan tanaman padi sawah, serangga tersebut dimasukkan ke dalam rearing atau kurungan serangga tersebut dan dilepaskan di satu titik pelepasan.

Setelah dilakukan pelepasan imago hama kepinding tanah di satu titik pelepasan, kemudian dilakukan pengamatan satu minggu setelah pelepasan selama 4 kali dengan interval waktu selama satu minggu.

Pengamatan dilakukan dengan mengamati jumlah imago yang ada pada tiap ember atau varietas yang telah diacak tersebut. Penelitian ini menggunakan metode Rancangan Acak Lengkap (RAL) dimana 5 jenis varietas sebagai perlakuan dengan 3 ulangan.

Data yang diperoleh kemudian dianalisis berdasarkan Analisis Sidik Ragam. Apabila jenis padi sawah berpengaruh terhadap hama kepinding tanah maka akan dilanjutkan dengan uji Beda Nyata Terkecil (BNT) $5 \%$

\section{HASIL PENELITIAN}

Berdasarkan hasil penelitian menunjukkan bahwa populasi hama $S$. coartata dengan rata-rata terbesar pada varietas Serayu sebanyak 6 ekor, kemudian diikuti oleh Membramo 3.75 ekor, Pertiwi 3,5 ekor, Cigeulis 3.5 ekor dan yang terendah Ciherang dengan rata-rata 3.25 ekor.

Berdasarkan hasil analisis sidik ragam menunjukkan bahwa jenis varietas padi sawah berpengaruh nyata terhadap keadaan populasi hama S. coartata. Berdasarkan hasil uji Beda Nyata Terkecil (BNT) menunjukkan bahwa rata-rata populasi varietas Membramo, Pertiwi, Ciherang dan Cigeulis tidak berbeda, tetapi rata-rata populasi hama S. coartata pada varietas Serayu berbeda nyata dengan varietas yang lainnya. Hal ini disebabkan karena varietas Serayu selain memiliki jumlah anakan yang cukup banyak dibanding dengan yang lain, varietas Serayu juga memiliki ukuran batang yang lebih kecil dibanding dengan varietas lainnya.

Jumlah anakan yang cukup banyak berpengaruh bukan saja kelembaban agar terjaga tapi juga dapat menjaga proses perkembangbiakan hama $S$. coartata yang melakukan hampir seluruh siklus hidupnya bersembunyi dibagian bawah tanaman padi sawah tersebut. Sedangkan pada varietas Ciherang memiliki batang yang lebih besar dan jumlah anakan yang lebih sedikit sehingga hama $S$. coartata kurang menyukai varietas tersebut. Menurut Suprihatno, dkk. (2010) jumlah anakan produktif Serayu yaitu sekitar $17-20$ anakan sedangkan Ciherang $13-15$ anakan, Cigeulis 14 16 anakan, Membramo 15 - 18 anakan dan Pertiwi $14-17$ anakan. 
Tabel 1. Populasi Imago S. coartata pada Beberapa Varietas Tanaman Padi Sawah

(Table 1. The Population of Adults S. coartata in Some Varieties of Rice Field Crops)

\begin{tabular}{clcc}
\hline No. & Varietas & Rata-rata (ekor) & Notasi \\
\hline 1. & Membramo & 3.75 & $\mathrm{~b}$ \\
2. & Serayu & 6 & $\mathrm{a}$ \\
3. & Pertiwi & 3.5 & $\mathrm{~b}$ \\
4. & Ciherang & 3.25 & $\mathrm{~b}$ \\
5. & Cigeulis & 3.5 & $\mathrm{~b}$ \\
\hline
\end{tabular}
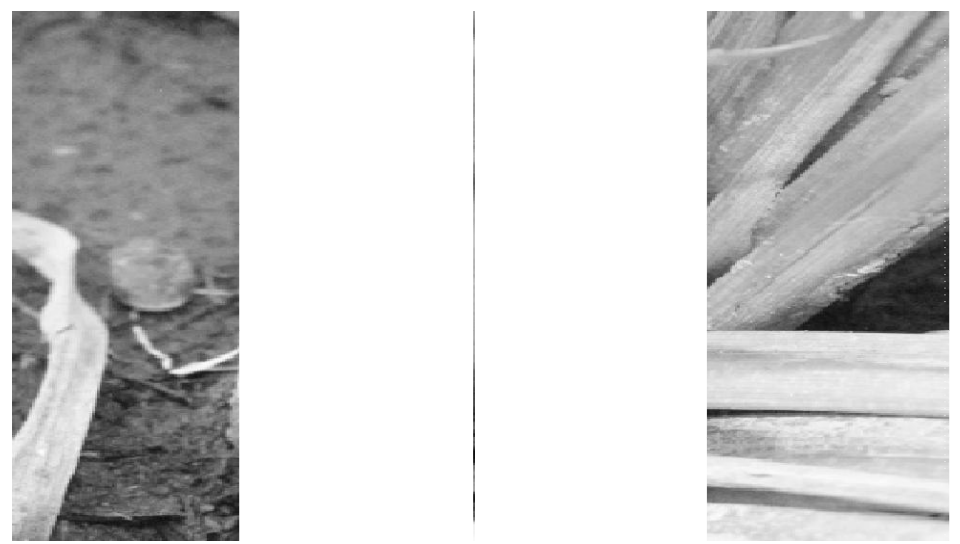

Gambar 1. S. coartata yang Bersembunyi di Tengah Bagian Pangkal Batang Padi Sawah

(Figure 1. S. coartata Hiding in the Middle of the Base of Rice Field Stalks)

Jumlah anakan berpengaruh terhadap kelembaban tanaman tersebut. Semakin banyak jumlah anakan kelembaban tanaman padi tersebut tetap terjaga. Menurut Kalshoven(1981), Kelembaban berpengaruh terhadap kegiatan kepinding tanah. Kepinding tanah pada kondisi tanah kering lebih sedikit dibandingkan pada tanah basah, diduga kepinding tanah lebih menyukai pada kondisi tanah basah atau lembab dimana untuk perkembangannya kepinding tanah lebih menyukai kelembaban tinggi. Kelembaban rendah akan menghambat proses metabolisme yang berarti memperlambat perkembangannya.

Varietas Serayu juga sangat cocok bagi hama $S$. coartata untuk melakukan oviposisi telur. Hama ini meletakkan telur pada bagian batang tanaman padi yang terjaga kelembaban pada tanaman padi tersebut. Menurut Liu (1933), serangga hama $S$. coartata diketahui berkembang baik pada kondisi tanaman kelembaban yang terjaga. Kelembaban di dasar tanaman padi diperlukan untuk kelangsungan hidup telur.

\section{KESIMPULAN}

Dari hasil analisis, dapat disimpulkan bahwa populasi hama Scotinophara coartata dengan rata-rata terbesar pada varietas Serayu sebanyak 6 ekor, kemudian diikuti oleh Membramo 3.75 ekor, Pertiwi 3,5 ekor, Cigeulis 3.5 ekor dan yang terendah Ciherang dengan rata-rata 3.25 ekor.

\section{DAFTAR PUSTAKA}

Darma, M D I. 2007. Swasembada Beras, Sebuah Impian?.http://www.balipost.co.id/balipostc etaK/2007/9/17/02.htm. Di akses tanggal 4 April 2016.

Gaib, S. 2011. Dampak Perobahan Iklim dan Perkembangan Organisme Pengganggu Tanaman. Materi TOT SL-Iklim Direktorat Jenderal Perlindungan Tanaman Pangan. PNPM-Jakarta. Diakses tgl 30 April 2016. 
Kalshoven, L.G.E. 1981. The Pests of Crops in Indonesia. Laan PA van der. penerjemah. Jakarta (ID): Ichtiar Baru van Hoeve. Terjemahan dari: De Plagen van de Cultuurgewassen in Indonesie. hIm 91-92. Diakses tgl 30 April 2016.

Liu, C.Y. 1933. Experiments on the Location and Submergence of the Eggs of Scotinophara lurida (Burm.) [in Chinese]. Entomol. Phytopathol.1: 12-16.

Manurung, S.O. dan M. Isumunadji, 2008. Morfologi dan Fisiologi Padi. hal 55-102 dalam Manurung, Ismunadji, Roechan, dan Suwardjo. Padi Buku 1. Pusat Penelitian dan Pengembangan Tanaman Padi. Badan Penelitian dan Pengembangan Pertanian, Bogor. Diakses tgl 22 April 2014.
Nurjanah, S. 2010. Kepinding Tanah (Scotinophora verminculata Thumb.) http://cybex.deptan. go.id/penyuluhan/kepinding-tanahscotinophora-verminculata-thumb. Diakses tanggal 22 April 2016.

Rimbing, J., J. Pelealu, B. Assa dan A. Pinaria. 2011. Studi Ekologi Serangan hama Scotinophara sp Pada Tanaman Padi Sawah di Sulawesi Utara Dalam Menunjang Pengendalian. Fakultas Pertanian Unsrat Manado.

Sembel, D.T. 2011. Dasar-dasar Perlindungan Tanaman. Fakultas Pertanian Unsrat Manado.

Suprihatno, B., A.A. Daradjat, Satoto dan S.E. Baehaki. 2010. Deskripsi Tanaman Padi. Balai Besar Penelitian Tanaman Padi. Departemen Pertanian. 2011. 
